\title{
A tanned cadaver
}

\section{Introduction}

Decomposition is a process of natural decay occurring in dead bodies which have not been preserved chemically or otherwise. The autolysis of cells by intracellular enzyme activity and putrefaction due to action of microorganisms are the basic underlying mechanisms of decomposition. The rapidity, depth and the type of decomposition are influenced by environmental factors such as heat, light, humidity, chemical nature of the media etc [1]. Mummification in hot dry climatic conditions and adipocere formation when buried in moist environments, are the other classic post mortem changes alternative to decomposition [2]. However, some cadavers buried under wet, salt rich soil show processing of the dead tissues which do not conform to usual post mortem changes.

\section{Observation}

It has repeatedly been observed that some dead bodies removed from grave sites showed well preserved features six months to several years after burial, contrary to complete skeletonization which generally occurs in three to six months after burial, in tropical conditions. These corpses were turned into stiff, cut resistant, light brown, moderately shrunken, moist but dehydrated masses. The facial features were generally preserved and the antemortem injuries could still be recognized. Internal viscera were shrunken but preserved. Bones were softened. Tissue patterns were destroyed and cellular details were not distinct on microscopy. The microscopic appearances were more like formalin preserved partly autolysed tissues. This phenomenon has been observed in five exhumed bodies from Jaffna in 1996 and in two from the Chemmani area in 2000. A similar appearance was noted in all 26 exhumed bodies of Hambantota tsunami victims (Figure 1) in 2006. The common feature of all these cases is that the burial sites were situated near the sea; lagoons or marshy lands, with salty water-rich sticky soil. There were no signs of mummification or the waxy, glossy appearance present in the case of adipocere formation. 


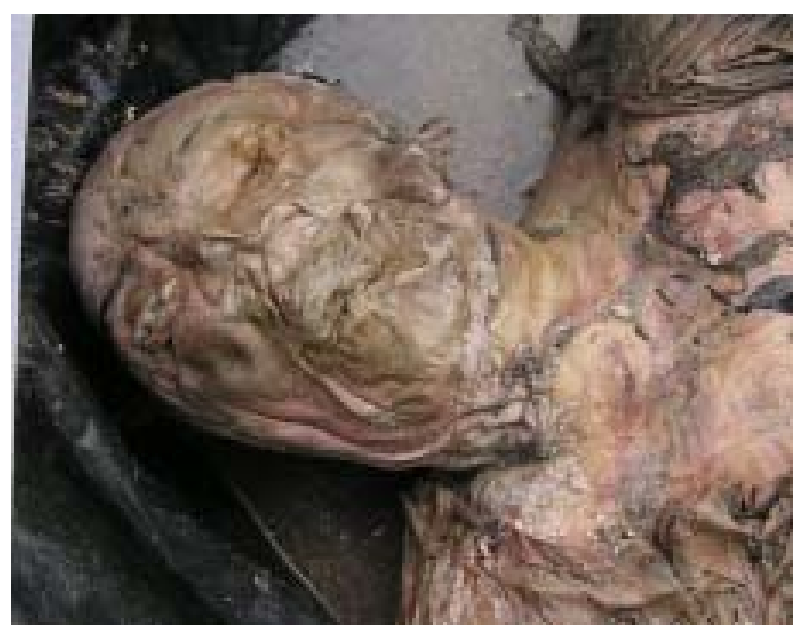

Figure 1. Facial features, tissues of the neck and the chest are fairly preserved one year after the burial Hambantota tsunami victim.

\section{Comment}

The transformation of a dead body into a stiff brownish mass, instead of undergoing the usual decomposition, has not been described in the forensic literature available to us, but is known to the forensic community in Russia [3] and other northern European countries. This variation in post mortem change was seen in dead bodies buried in marshy areas, especially in the Siberian desert [4]. The "tanning" is probably due to processing of tissues by complex salts and other chemical substances which have diffused into the dead tissues from soil beds in these areas [5]. The process has some features in common with artificial chemical treatment of animal coats in leather industry and the word "dubleon" in Russian refers to a processed, tanned animal coat. According to our observations, "dubleon" transformation of a cadaver is a natural process, alternative to decomposition, mummification and adipocere formation. However, in-depth scientific research and surveys are yet to be conducted to investigate the biochemical basis of this phenomenon. The advantage of "dubleon" transformation is that features of identification and antemortem trauma are preserved after death, and that it may be developed into an economical method for temporary preservation of a large number of dead bodies in disaster situations.

\section{References}

1. Di Maio VJM, Dana SE. Handbook of forensic pathology. Texas. 1st South Asian Edition. Lades Bioscience; 1999: 24-1.

2. Rodrigues WC, Bass WM. Decomposition of buried bodies and methods that may aid in their location. Journal of Forensic Sciences 1985; 30: 836-52.

3. Barinov EKH, Fadeev SP. Unusual cases of the long-term preservation of dead bodies. Sudebno Medicinskaya Ekspertiza (Russian) 1999; 42: 38-40.

4. Mathishewa AA, Denkovskovo AP. Sudyebnaya Medicina (forensic medicine). Moscow: 2nd Edition. Medicina; 1976: 324-2.

5. Pilleri G, Schwab H. Morphological structures in 2100year old celtic brains. Man, New Series 1970; 4: 701-2.

P R Ruwanpura and J Warushahennadi, Medico-Legal Unit, Teaching Hospital, Karapitiya, Galle, Sri Lanka. Correspondence: PRR, e-mail: <rohanr@sltnet.lk >. Received 8 May 2008 and accepted 8 November 2008. Competing interests: none declared. 